\title{
Grzeczność w polityce
}

\author{
Jagoda Przybysz
}

Uniwersytet Łódzki

\begin{abstract}
Abstrakt. Celem artykułu jest dokonanie analizy kategorii i form aktów grzeczności w wystąpieniach czołowych polityków polskiego Sejmu. Interpretacje wypowiedzi skupiają się zarówno na lingwistycznych, jak i kulturowych strategiach grzeczności oraz konfrontują je z teorią grzeczności językowej (E. Goffman, P. Brown, S. Levinson) przy wykorzystaniu analizy wizualnej.
\end{abstract}

Słowa kluczowe: polityka, grzeczność, polska polityka, etykieta, etyka poselska, savoir vivre w Sejmie, pozorna grzeczność, reguły grzecznościowe, socjologia emocji, teoria grzeczności językowej, twarz, zachowanie twarzy

\section{Wstęp}

Etykietę w świecie polityki i dyplomacji postrzegano od zawsze jako wyraz znajomości zasad dobrego wychowania, była oznaką przynależności do danej grupy społecznej - dostępna nielicznym i wtajemniczonym, znającym dokładnie kodeksy dworskich kanonów zachowania. Znajomość reguł zachowania umożliwiała od zarania dziejów utrzymywanie poprawnych stosunków z partnerami politycznymi (w szczególności na arenie międzynarodowej), ułatwiała rozwiązywanie konfliktów i ujednolicała kanony poprawnego zachowania. W dzisiejszych czasach etykieta oraz dobre maniery są zarezerwowane nie tylko dla wybranych, pomi- 
mo to jednak każdy z polityków prezentuje własny system zasad poprawnego zachowania. System ten oparty jest w mniejszym lub większym stopniu na zasadach savoir-vivre’u i znajomości protokołów (w tym dyplomatycznego oraz precedencji stanowisk w Polsce), praktyka jednak - jak to często bywa - nie idzie w parze z teorią, a stosowanie zasad dobrego wychowania na co dzień przyjmuje często formę pozornej grzeczności.

\section{Charakterystyka pojęcia grzeczności}

Grzeczność definiowana jest jako uprzejmy, delikatny, świadczący o dobrym wychowaniu stosunek do ludzi, uprzejmość, delikatność (Słownik Języka Polskiego 1958-1969). W potocznym rozumieniu pod pojęciem grzeczności kryją się cechy świadczące o uprzejmości, spokoju, dobrym wychowaniu, szacunku i o pewnego rodzaju spolegliwości, ustępowaniu. Przez lata również zmieniały się językowe formy na określenie pojęcia grzeczności. Słownik Języka Polskiego S. B. Lindego z 1815 roku przytacza również pojęcia: grzecznouprzejmy - z uprzejmością grzeczny; grzecznopoczciwy - pełen pozornej cnoty i grzeczności; oraz grzecznodumny - grzeczny i dumny (Słownik Języka Polskiego 1815).

Nie ma dokumentu, który w sposób dosłowny obligowałby posłów i polityków do stosowania konkretnych zabiegów grzecznościowych, najczęściej zobowiązani są oni do stosowania ogólnych zasad dobrego wychowania oraz zasad zgodnych z etyką poselską, która to nadrzędnie traktuje o zasadzie jawności, bezinteresowności, rzetelności, odpowiedzialności oraz dbałości o dobre imię Sejmu (Uchwała Sejmu Rzeczypospolitej Polskiej 1998).

W kontaktach na arenie międzynarodowej politycy odsyłani są do ścisłych zasad protokołu dyplomatycznego, a protokół ten w szczególności po przystąpieniu przez Polskę do UE wykorzystywany jest również w parlamencie, określając nie tylko organi- 
zację spotkań i korespondencji, ale również sposób zachowania podczas licznych spotkań, konferencji, posiedzeń o charakterze formalnym i nieformalnym.

Ostatnim już dokumentem odnoszącym się do zasad dobrego zachowania jest Precedencja Stanowisk Publicznych w Polsce (Dziewulak 2009). Opracowanie to zawiera ścisłe reguły dotyczące zasad ustalania pierwszeństwa wypowiedzi, stanowisk, kolejności witania, zajmowania miejsc, podpisywania dokumentów itp. T. Orłowski (były dyrektor Protokołu Dyplomatycznego MSZ) w opracowaniu Protokół Dyplomatyczny, ceremoniał \& etykieta (Orłowski 2006) w sposób dokładny opisuje precedencję najważniejszych stanowisk w Polsce, na pierwszych miejscach wymieniając:

1. Prezydenta Rzeczypospolitej Polskiej,

2. Marszałka Sejmu RP,

3. Marszałka Senatu RP,

4. Prezesa Rady Ministrów,

a w dalszej części: wiceprezesów, wicemarszałków, prezesów, rzeczników, przewodniczących oraz posłów na Sejm (poz. 18) oraz senatorów (poz. 19).

Wszystkie te formalne zabiegi mają na celu nadanie statusu odpowiednim funkcjom i organom państwowym, dodanie im powagi i rangi oraz ścisłe określenie panujących norm i zasad. W kontekście prowadzonych rozważań odnoszących się do konkretnych wypowiedzi polityków, analizie poddane zostaną zarówno formy wypowiedzi (stosowanie się do zasad dobrego wychowania w kontekście werbalnym i kulturowym), jak i jej ramy - stosowanie się do hierarchicznego modelu precedencji oraz stosowanie zabiegów językowych z pozoru wyrażających grzeczność i uprzejmość, a stanowiących kategorię grzeczności pozornej. Aktualny zatem staje się podział na grzeczność-szczerość i grzeczność-hipokryzję, czyli grzeczność serca i grzeczność udawaną (Dąbrowska 1991). 


\section{Językowe i niejęzykowe elementy etykiety}

W języku polskim występuje szereg sformułowań, tzw. aktów grzecznościowych - powitań, podziękowań, pożegnań, przeprosin, pozdrowień, życzeń, gratulacji, które pomimo braku gramatycznego rozróżnienia od lat są obiektem badań różnych grup, od lingwistów i socjolingwistów poczynając. Interdyscyplinarne badania specjalistów z różnych dziedzin przyczyniły się bezpośrednio do powstania pewnej odmiany interakcjonizmu społecznego, a tym samym poddania próbie tłumaczenia i opisywania językowych i pozajęzykowych zjawisk w kontaktach międzyludzkich (Tomiczek 1991).

Językowe elementy etykiety w sposób bezpośredni przy użyciu szablonów językowych (Marcjanik 1991) wyrażają werbalnie „kindersztubę" mówcy. Szablony te z powodzeniem mogą być również modyfikowane indywidualnie, przy czym nadal zwroty powszechnie uznawane za grzecznościowe stanowią obudowę całych wypowiedzi. Przykładami szablonów są zwroty: Moje najlepsze gratulacje; Najmocniej Pana przepraszam; Dziękuje $z$ całego serca.

Następną kategorię wyrażeń grzecznościowych stanowią wszelkie formy adresatywne: Panie Profesorze; Mamo; Ciociu. Formy te powszechnie uznawane są za tytuły, a ich stosowanie traktowane jest jako wyraz okazywania szacunku rozmówcy.

Ostatnimi strukturami gramatycznymi uznawanymi za formy grzecznościowe są orzeczenia złożone (Pozwole sobie przypomnieć...; Niech wolno mi będzie powiedzieć, że...; Pragnę dodać...), zdania składnikowe wypowiedzi złożonych (Jeżeli Pan pozwoli, to...; Wybacz, że...) oraz niektóre z modalnych konstrukcji składniowych, takie jak np. tryb pytający w funkcji trybu rozkazującego (Czy mógłby Pan skasować mi bilet?) (Marcjanik 1991). 
Analizując rozwój badań nad językowymi i pozajęzykowymi formami grzeczności, należy wspomnieć o socjosemantyce i gramatyce transformacyjnej. Lata 70. i 80. ubiegłego stulecia obfitowały w nowe podejścia metodologiczne w badaniach nad językiem i komunikacją.

Paul Grice pokusił się o sformułowanie zasad, maksym komunikacji, które w konsekwencji posłużyły jako możliwe strategie grzeczności. Późniejsze zmodyfikowanie maksym przez Robina Lakoffa sprowadziło reguły grzecznościowe w komunikacji do dwóch głównych pojęć: be clear i be polite (be impose, give options, be friendly). W sposób prosty zatem przeciwstawienie się powyższym zasadom skutkowało niegrzecznym zachowaniem w rozmowie (Tomiczek 1991).

Nowe światło na pojęcie grzeczności rzucają badania stosunków interpersonalnych oraz analizy interakcji Ervinga Goffmanna. Wprowadzone przez niego pojęcie "face” zakładało przy emocjonalnym zaangażowaniu partnerów rozmowy troskę o zachowanie własnej twarzy i twarzy partnera i ukazywało współwystępowanie tzw. twarzy pozytywnej i negatywnej podczas interakcji. Twarz pozytywna wyraża zabiegi o uznanie przez innych własnej, pozytywnej wartości. Twarz negatywna natomiast odnosi się do działań mających na celu obronę własnej wolności, opinii, działań (Goffman 2006).

Pierwszymi badaczami, którzy celowo zajęli się problematyką grzeczności wypowiedzi, byli korzystający z dorobku wcześniejszych badaczy (w szczególności P. Grice’a i E. Goffmana) Penelope Brown i Stephen Levinson w rozprawie całkowicie poświęconej temu tematowi pt. Universals in Language Usage: Politeness Phenomena (1978). Stworzona przez tych badaczy teoria grzeczności, odwołując się do pojęcia twarzy i potrzeby każdego rozmówcy do bycia swobodnym i szanowanym w rozmowie, zakłada występowanie tzw. aktów zagrażających twarzy (face threatening acts). W klasyfikacji tych aktów występują 
akty zagrażające negatywnej i pozytywnej twarzy słuchającego i przemawiającego. Badacze ci wyróżnili 5 generalnych strategii reakcji:

1) otwarta bez zahamowań, bez występowania działań naprawczych ratujących twarz współrozmówcy;

2) otwarta z działaniem naprawczym - uprzejmość pozytywna, przy jednoczesnym wyrażaniu aprobaty, uczuć dla słuchającego;

3) otwarta z działaniem naprawczym - uprzejmość negatywna, przy uznaniu potrzeb negatywnej twarzy słuchającego;

4) z ukrycia, przy zachowaniu maksimum możliwej uprzejmości i unikaniu odpowiedzialności;

5) unikanie - najbardziej uprzejma strategia mająca na celu całkowite unikanie aktów zagrażających twarzy (Brown, Levinson 1978).

Analizując pozajęzykowe aspekty grzeczności, należy zwrócić uwagę na ich kulturowy wymiar, a tym samym możliwość prawidłowej interpretacji tylko w danej społeczności kulturowej. Na pozajęzykowe elementy w szczególności składają się przekazy niewerbalne. Do przekazów tych zaliczyć można: pauzy, milczenie, natężenie głosu, intonację, akcent, melodię wypowiedzi, tempo mowy oraz tembr głosu. Do paraleksykalnych form niewerbalnych zaliczyć można zespół środków wyrazu towarzyszących wypowiedziom: śmiech, chrząknięcia, kaszlnięcia, gwizdnięcia oraz jąkanie. Kolejną grupą tworzącą przekaz językowy niewerbalny kanałem wizualnym są środki kinezyczne: wygląd, ubiór, zachowanie, mimika, ruchy głowy, ciała, gesty stanowiące proceder odgrywania roli, wdziewania maski. Ostatnim elementem jest tzw. proksemika, czyli relacje przestrzenne między uczestnikami interakcji, wypowiedzi, a tym samym różne typy dystansów między uczestnikami rozmowy (Peisert 1991). 


\section{Analiza materiałów badawczych}

Poniższe dane analizowane były w ramach projektu „Emocje w polityce” realizowanego przez Katedrę Socjologii Organizacji i Zarządzania Uniwersytetu Łódzkiego w ramach zajęć z tematu „Metody jakościowe”. Materiał badawczy stanowią dwa wystąpienia sejmowe - prezesa Klubu Parlamentarnego Prawo i Sprawiedliwość Jarosława Kaczyńskiego oraz posła Antoniego Macierewicza. Materiały audiowizualne dostępne były na portalu YouTube, następnie sporządzono ich transkrypcję i zakodowano, poddając szczegółowej interpretacji.

Pierwszy z filmików, zatytułowany przez użytkownika videosejm Piotrek Jarosław Kaczyński wystąpienie z 23 stycznia 2014 r., trwa 11 min. 14 sek. [dostęp 12.06.2014].

W wystąpieniu udział biorą Jarosław Kaczyński - prezes Klubu Parlamentarnego Prawo i Sprawiedliwość oraz Ewa Kopacz - Marszałek Sejmu RP VII kadencji. Wystąpienie prezesa PiS jest odpowiedzią na wystąpienie posłanki Klubu Parlamentarnego Platformy Obywatelskiej - Elżbiety Radziszewskiej w sprawie uzasadnienia wniosku o wotum nieufności dla Ministra Zdrowia Bartosza Arłukowicza.

Drugim filmem opublikowanym przez portal sejmometr jest film zatytułowany [143/376] Pani Marszałku! Przepraszam! Proszę wybaczyć Pani Marszałek..., opublikowany 18 maja 2013 r. Film trwa 9 min. 24 sek. i stanowi wypowiedź Antoniego Macierewicza, skierowaną w sposób bezpośredni do Radosława Sikorskiego (jako obecnego na sali przedstawiciela partii rządzącej oraz Ministra Spraw Zagranicznych) [dostęp 13.06.2014].

W wypowiedziach posłów przeanalizowano wszystkie sekwencje wypowiedzi podzielone na bloki czasowe zgodnie $\mathrm{z}$ wątkiem i tematyką wypowiadanych słów. Transkrypcja obejmowała również zapis pauz, modulowania głosu czy zmian w intonacji. Już $\mathrm{w}$ momencie transkrybowania można dostrzec elementy analizy 
i interpretacji dokonanej zarówno w uzyskanych danych audio, jak i danych wizualnych.

Analizie poddano występowanie lub brak występowania w wypowiedziach polityków wymienionych wyżej form grzecznościowych: aktów grzecznościowych, stosowania szablonów językowych, form adresatywnych, formułowania wypowiedzi w formie orzeczeń złożonych, oraz niewerbalne przekazy mówców celem poddania ich ocenie w wymienionych wyżej kategoriach.

Analizowane fragmenty posiedzeń sejmowych z dnia 15 grudnia 2011 oraz 23 stycznia 2014 r. przenoszą nas w czasy Sejmu VII kadencji wyłonionego w wyborach 9 października 2011 r. W tym okresie obowiązki premiera pełnił Donald Tusk (Platforma Obywatelska), a marszałkiem Sejmu była Ewa Kopacz (Platforma Obywatelska). Platforma Obywatelska (PO) posiadała większość głosów wyborców (45\% mandatów), a Klub Prawa i Sprawiedliwości w wyniku wyborów zajął drugie miejsce, uzyskując niespełna 35\% mandatów. Na koalicję rządzącą składał się sojusz PO i Polskiego Stronnictwa Ludowego (PSL).

\subsection{Analiza wystąpienia Jarosława Kaczyńskiego z 23 stycznia 2014 r. $^{1}$}

Analizowana wypowiedź przewodniczącego Klubu Parlamentarnego Prawa i Sprawiedliwości Jarosława Kaczyńskiego stanowi bezpośrednie odniesienie do wypowiedzi przedmówczyni - poseł Elżbiety Radziszewskiej (PO). Tematyka obu wypowiedzi odnosiła się do wniosku o wyrażenie wotum nieufności wobec Ministra Zdrowia Bartosza Arłukowicza przez posłankę PiS Annę Zalewską.

Klub Parlamentarny Prawa i Sprawiedliwości w uzasadnieniu wniosku o wotum nieufności przywołał złą ocenę kondycji służ-

1 https://www.youtube.com/watch?v=ATDvq8p0Ft0\&list=PLoKqIN5JjGgULPIBOswukSLCAfMijOUIY [dostęp 12.06.2014]. 
by zdrowia, wydłużające się kolejki do lekarzy, szkodliwy proces komercjalizacji szpitali, błędny podział środków, niezrealizowane obietnice wyborcze oraz konflikt z NFZ i lekarzami (por. Druk nr 2015, Sejm Rzeczpospolitej Polskiej VII kadencja).

Wniosek wpłynął do Sejmu 12 grudnia 2013 r., a wraz z początkiem roku poddany został ocenie w komisji (ocena negatywna) oraz rozpatrzeniu na forum Sejmu. Wniosku nie przyjęto, gdyż 215 posłów głosowało za, a 233 przeciw (głosowanie z dnia 24 stycznia 2014 r.).

Jarosław Kaczyński, powitany gromkimi brawami przez członków własnej partii podczas wejścia na mównicę sejmową, swoją wypowiedź rozpoczyna standardowo od grzecznościowej formuły adresatywnej mającej charakter aktu grzecznościowego: „Wysoki Sejmie”. W wypowiedzi pomija osobę Pani Marszałek, nie kierując jakby do niej bezpośrednio swoich słów. Następnie używa w odwrotnym zamiarze znaczeniowym słów mających wydźwięk podziękowania i ugrzecznionej formy ironii, mówiąc: „Ja chciałem przede wszystkim Pani Poseł Radziszewskiej serdecznie podziękować, naprawdę bardzo serdecznie, no bo bardzo jasno zarysowana została tutaj różnica między dwoma partiami, różnica zdań". Wypowiadając te słowa, prezes Kaczyński uśmiecha się i marszczy czoło, brwi oraz gestykuluje, czym podkreśla ironiczny charakter swoich podziękowań.

Następnie odwołując się do wypowiedzi posłanki Anny Zalewskiej (Klub Parlamentarny PiS), używa zintensyfikowanej formy oceny „w doskonałym przemówieniu Pani Poseł Zalewskiej”, podkreślając tym samym słuszność własnych racji.

W następnej kolejności prezes Kaczyński, wyliczając zaniedbania Ministra Zdrowia i brak ich wymienienia przez Panią Poseł Radziszewską w przemówieniu poprzedzającym, znów serdecznie jej dziękuje, kierując swój komunikat w sposób bezpośredni: „za to też serdecznie dziękuję”. W dalszym ciągu wypo- 
wiedzi można dostrzec stosowanie innych adresatywnych form: „Szanowni Państwo”, „Proszę Państwa”.

W niektórych swoich wypowiedziach jednak, jakby celowo, prezes Kaczyński nie stosuje grzecznościowych form adresatywnych, mówiąc o „systemie Tuska” zamiast Premiera Tuska, celowo odbiera należny z powodu zajmowanej pozycji i pełnionej funkcji szacunek i uznanie. Przechodząc do merytorycznej krytyki bezpośredniej ministra Arłukowicza, prezes Kaczyński stosuje, uznawane za grzecznościowe formy w wypowiedzi, orzeczenia złożone w słowach retorycznego pytania: „No $i$ w tym momencie można zapytać, a cóż ma z tym wspólnego Minister Arłukowicz?" Wyrażenie krytyki w pytaniu retorycznym najczęściej pełni funkcję ironicznego wzmocnienia charakteru wypowiedzi i, niejako w białych rękawiczkach, służy ośmieszeniu partnera rozmowy bądź osoby, której temat dotyczy. Po czym następuje fala zarzutów ukazująca brak zasadności wyboru ministra na piastowane przez niego stanowisko.

W kolejnych słowach charakteryzujących obecnego na sali ministra Arłukowicza, skierowanych w 3. osobie liczby pojedynczej, prezes Kaczyński mówi: „no bo niektórzy uważaja, że jest sympatyczny, miły i w tej sprawie nie będę dyskutował [...] pewnie jest człowiekiem rozgarniętym". Słowa te, pozornie wyrażające pochwały, ale wypowiedziane nie we własnym imieniu, mają na celu zasugerowanie istnienia sytuacji wręcz odwrotnej, bądź też w zestawieniu z przywoływanymi faktami mają ukazać, jak bardzo opinie te są mylne. Brak bezpośredniości wypowiedzi w tym przypadku i gramatyczny unik są środkiem wzmacniającym niechęć i brak szacunku do osoby będącej w centrum zainteresowania mówcy.

Wypowiedź „a my mamy tutaj radykalnie inne zdanie” w swojej formie w sposób jawny i konkretny, bez zbędnych upiększeń, ukazuje merytoryczny dystans pomiędzy obiema grupami rozmówców i zarazem przedstawicielami ugrupowań politycznych. Taki wprost wyrażony komunikat zawiera się w grzecznościowej formie wypowiedzi, prezentując zgodnie z klasyfikacją Brown \& 
Levinson strategię otwartą bez zahamowań (on record boldly). W wypowiedziach tych nie można dostrzec żadnych prób łagodzenia wypowiedzi czy stosowania działań naprawczych.
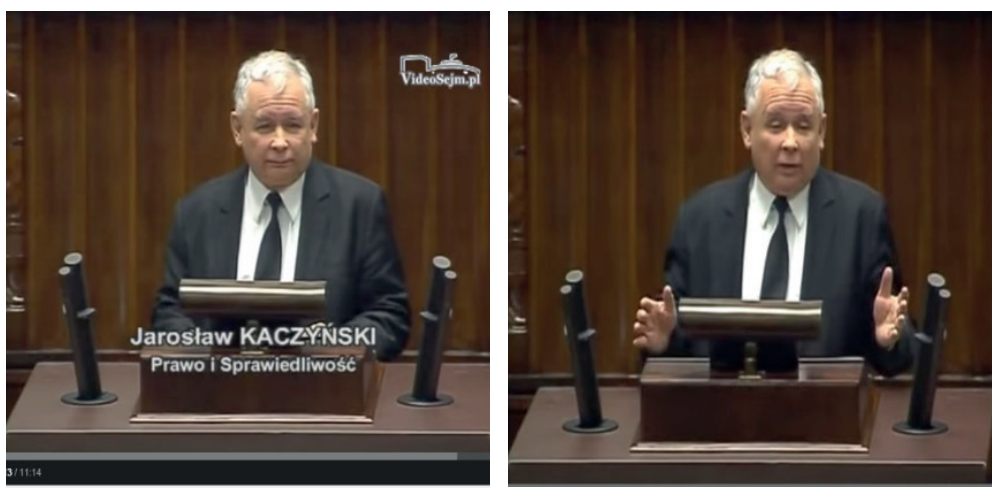

Fot. 1, 2. Jarosław Kaczyński - strategia otwarta bez zahamowań Źródło: http://youtu.be/ATDvq8p0Ft0?list=P

Kolejny zwrot zastosowany przez mówcę, tym razem skierowany bezpośrednio do przedmówczyni, z nawiązaniem $\mathrm{z}$ nią kontaktu wzrokowego („Pani Poseł była łaskawa powiedzieć, że...”), jest próbą odwrócenia znaczenia zastosowania grzecznościowego zwrotu „bycia łaskawym”. Stosując ten zabieg leksykalny, w tym samym zdaniu autor wypowiedzi mówi o braku jego słuszności. Zachowanie to ma więc znamiona tylko pozornej grzeczności, wyrażonej słowami, a znaczeniowo przeciwnej.

Ostatnia wypowiedź prezesa Kaczyńskiego analizowana pod kątem używanych kategorii grzecznościowych dotyczy sposobu formułowania próśb z zastosowaniem powszechnie używanych szablonów językowych - „Bardzo proszę, żeby to wyłaczyć, Pani Poseł nie była $w$ ten sposób prześladowana”. Użycie prośby w prezentowanej formie, oprócz podkreślenia dystansu pomiędzy nadawcą prośby (J. Kaczyńskim) a jej adresatem (E. Kopacz), 
wskazuje na niemalże rozkazujący tryb wypowiedzi nadawcy i intencyjnie ukazuje, iż prośba ta nie do końca jest prośbą, choć nosi takie znamiona konstrukcyjne, ale zawiera w sobie elementy żądania i wymuszenia zachowania oczekiwanego przez nadawcę.

\subsection{Analiza wystąpienia Antoniego Macierewicza²}

Analizowany fragment wypowiedzi posła Antoniego Macierewicza odnosi się do czasów, gdy Radosław Sikorski (PO) piastował stanowisko Ministra Spraw Zagranicznych, a Antoni Macierewicz kierował Zespołem Parlamentarnym ds. Zbadania Przyczyn Katastrofy TU-154 M z 10 kwietnia 2010 r.

Przemówienie posła Macierewicza bezpośrednio odnosi się do złożonego przez Witolda Waszczykowskiego wniosku o wotum nieufności wobec Ministra Spraw Zagranicznych Radosława Sikorskiego. Wniosek ten wpłynął do Sejmu 1 grudnia 2011 r. (na 14 dni przed wygłoszonym przemówieniem), a głosowanie odbyło się nazajutrz, tj. 16 grudnia 2011 r. W wyniku głosowania wniosku nie przyjęto (292 przeciw, 152 za). Bezpośrednie zarzuty kierowane pod adresem ministra Sikorskiego dotyczyły rzekomej dyskredytacji przez niego pozycji Polski w Europie i na świecie, przeorientowania stosunków politycznych z Rosją - wasalizacji Polski oraz dokonywania zasadniczych zmian w działaniu UE (por. Druk nr 43, Sejm Rzeczpospolitej Polskiej, VII Kadencja). Poseł Macierewicz w swoim przemówieniu kieruje zarzuty pod adresem Radosława Sikorskiego, dodatkowo motywując potrzebę jego odwołania z funkcji Ministra Spraw Zagranicznych.

Przemówienie posła Antoniego Macierewicza obfituje w szereg zabiegów językowych wyrażających dbałość o formalny charakter wypowiedzi oraz jej wyszukany i grzeczny charakter. Już rozpo-

2 https://www.youtube.com/watch?v=U5OpQyldJto [dostęp 13.06.2014]. 
czynając swoje przemówienie od początkowego błędu, w sposób wyraźnie szczery przeprasza, kierując się adresatywnie do Pani Marszałek oraz Wysokiej Izby, nadając również brzmieniu głosu bardzo oficjalny i podniosły charakter. W wypowiedzi tej doszukać się można utartych szablonów językowych („Przepraszam; Prosze wybaczyc"), nieposzerzonych w żadnym stopniu o zindywidualizowany charakter. Kolejne fragmenty okraszone przymiotnikami "niesłychanie ważna, kluczowa” mają na celu podniesienie rangi własnej wypowiedzi, a skontrastowane $\mathrm{z}$ aktem grzeczności, wyrażania żalu wobec zachowania rządzących oraz partii koalicyjnych ukazują celowość zastosowanego zabiegu. Poseł Macierewicz, wypowiadając słowa „prowadzona ona była ze strony tych, którzy rządza i przedstawicieli klubów lewicy, którzy pragna przyłączyć się do Państwa rządów”, wyraźnie zmienia ton głosu na bardziej dobitny, dosadny, żywo i celowo wskazując i gestykulując oraz całą swoją postawą wyrażając jawną dezaprobatę takiego działania. Wypowiedź „to gratulacje, które składam na ręce Pana Ministra, jako najwyższego urzędnika państwowego koalicji tutaj obecnego, zyskaliście dzisiaj wspaniałych sojuszników" w sposób niepozostawiający wątpliwości wskazuje bezpośredniego jej odbiorcę i sama w sobie stanowi o przewrotnym charakterze użytych słów. Akty grzecznościowe w postaci gratulacji oraz określenie atakowanych koalicjantów mianem wspaniałych to ironiczne zabiegi mające za zadanie, przy wykazaniu najwyższej klasy pozornej grzeczności, ośmieszenie współrozmówców oraz stanowiące bezpośredni akt zagrożenia twarzy. Intencje mówcy odczytywane są bowiem jednoznacznie z następującej po tych pozornych komplementach krytyki.

Poseł Macierewicz z uśmiechem na ustach przywołuje nazwisko Leszka Millera, oskarżając go o „nierozliczenie z moskiewskiej pożyczki i pragnienie zapisania się do nowego państwa federacyjnego". Metaforyczność wypowiedzi oraz bezpośredniość komunikatu przy sugestywnej mowie ciała mówcy oraz żywej ge- 
stykulacji i podniesionym tembrze głosu wskazują na sarkazm i potępienie. Celowe zrezygnowanie z formy „Państwa”, na rzecz „za wasza pomoca”, wskazuje na intencyjne działanie zmierzające do umniejszenia szacunku i niechęć użycia należnej formy, a tym samym wyraża już nie tylko pozorną grzeczność, ale wręcz jej brak w wypowiedzi posła Macierewicza.

W kolejnym fragmencie wypowiedzi, skierowanym bezpośrednio do wymienionego z nazwiska Pana Ministra Sikorskiego, odnosi się do Klubu Palikota i chęci „zalegalizowania przez niego heroiny", sugerując tym samym wspólnotę jego poglądów z partią rządzącą. Ponownie użyty zostaje akt pozornie grzecznościowy - złożenie gratulacji („moje gratulacje”), który oczywiście ma na celu w sposób sarkastyczny ukazanie wręcz przeciwnego stanowiska przemawiającego.

Szereg bezpośrednich zwrotów do Ministra Sikorskiego (która Pan; Pana zdaniem; Pan przywołał; Pan nas pcha) oraz używanie pytań retorycznych z dużą liczbą określeń i metafor nacechowane jest wieloma przypadkami zagrożenia twarzy, co wskazuje na strategię otwartą bez zahamowań i niesilenie się nawet na stosowanie jakichkolwiek językowych zabiegów mających na celu działania naprawcze. Komunikaty wypowiadane przez posła Macierewicza mają wręcz charakter werbalnych, bezpośrednich ataków na ministra Sikorskiego.

W sposób przewrotny również poseł Macierewicz mówi, iż „szanuje i rozumie" przyjętą strategię, dając zaraz do zrozumienia, jak niezasadne i samolubne jest takie postępowanie. Formy „i Pan nawet nam powiedział, za co dziękuje”" są kolejnym przykładem użycia w sposób pozornie grzeczny, a zarazem przewrotny aktu grzecznościowego, jakim jest zastosowanie szablonu podziękowania.

Zwroty „Przykładacie Państwo rękę; Państwo cały czas mówicie" są przykładem adresatywnej formy wypowiedzi posła Macierewicza skierowanej bezpośrednio do ministra Sikorskiego oraz w domyśle do reprezentowanego przez niego rządu. 
„Jak Pan zapewne pamięta, albo i nie" - to wyraz pozornie grzecznego przywołania, w interpretacji jednak mającego zasugerować, iż zapewne odbiorca komunikatu nie pamięta lub nie wie, a był przecież upominany i ostrzegany o skutkach i konsekwencjach postępowania.

„Państwo szermujecie; Państwo forsujacc, wpychacie nas” - używanie mocno agresywnych i oskarżających słów bezpośrednio i personalnie dotykających ministra Sikorskiego jako odpowiedzialnego za reprezentowanie koalicji i rządu.

„Ja przyjmuje do wiadomości miny, jakie teraz Pan Minister stroi, bo mina blazna jest często przez Pana przyjmowana publicznie, ale Pan jest Ministrem Polski i Spraw Zagranicznych i ma Pan obowiazek..." - bezpośredni atak personalny na ministra Sikorskiego, bez możliwości obrony z jego strony, stosowanie strategii otwartej bez zahamowań przy jednoczesnym braku dbałości i troski o samopoczucie i emocje rozmówcy - próba ośmieszenia go na forum oraz przyrównanie do błazna.

Specyficzna jest również forma prośby posła Macierewicza o przedłużenie czasu - „Pani Marszałek, rozumiem, że Pani przedłużyła ten czas przerywany przez tamtych postów. Dziękuje Pani Marszałek bardzo za przedłużenie czasu". Poseł Macierewicz w sposób bezpośredni zwrócił się adresatywnie do Marszałkini, kierując zdanie w trybie oznajmującym, które wyraziło przypuszczenie przedłużenia czasu, de facto będące specyficznym rodzajem prośby o takie właśnie rozwiązanie, bez użycia nawet słowa proszę. Zdaniem tym niejako poucza Panią Marszałek o zasadności danego rozwiązania i bez reakcji z jej strony następuje podziękowanie za wykonanie polecenia.

„Niestety olbrzymia część posłów dzisiaj się wypowiadajacych nie zna historii Polski i podstawowych zasad" - pozorne wyrażenie żalu, przy czym celem wypowiedzi nie jest wyrażenie żalu z powodu istniejącej sytuacji i niewiedzy, ale obnażenie i ośmieszenie braków posiadanych zdaniem przema- 
wiającego przez obecnych posłów. Wypowiedź ta jest również wstępem do kolejnej wypowiedzi-anegdoty i stanowi zarazem usprawiedliwienie jej użycia.

\section{Wnioski}

W analizowanych filmach dostrzec można tendencje do stosowania zabiegów formalnych o charakterze aktów grzecznościowych, szczególnie w formie powitań, dbałości o formę tytularną, pożegnań, podziękowań i gratulacji. Wszystkie te formy jednak oprócz powitań mają drugie dno i intencyjnie reprezentują zgoła inne stanowisko niż by się mogło z pozoru wydawać. Mamy tu do czynienia z kategorią tzw. pozornej grzeczności, stosowanie której niemalże w białych rękawiczkach i przy pozornym zachowaniu najwyższych norm poprawności językowej ma na celu ośmieszenie, obnażanie i obśmianie odbiorcy, adresata, rozmówcy. W większości przypadków formy adresatywne używane były w zgodzie z obowiązującymi normami kulturowo-językowymi. Dostrzec można natomiast celowe zaniechania w stosowaniu form adresatywnych, pomijanie ich, celowe zapominanie i używanie form tytularnych celem umniejszenia wagi, rangi i tym samym nieokazanie szacunku.

Kolejną cechę wspólną stanowi sposób formułowania próśb przez mówców. Prośby te konstruowane są w impresywny sposób narzucający adresatowi prośby działanie zgodne z wolą przemawiającego i mają bardziej charakter dyspozycji aniżeli realnych próśb rozumianych jako klasyczny zabieg nie tylko w wymiarze językowym, ale i kulturowym (liczenie się z odmową adresata prośby i podporządkowanie się).

Masowy charakter komunikacji przyczynia się do potoczności wypowiedzi. Nadawcy komunikatów, mając na względzie obecność mass mediów, a tym samym świadomość emisji wła- 
snych wypowiedzi i odbioru ich przez szerokie grono odbiorców, w stosowanych aktach perswazji używają kolokwializmów celem wzmocnienia autentyczności wypowiedzi oraz akcentują jej emocjonalny charakter. Proceder ten ma wywierać tym samym wpływ na kanon wzorców zachowań grzecznościowych. Dostrzegalne kurtuazyjne formy zachowania dobrych manier podszyte są jednak tylko pozorną grzecznością, a intencyjnie przejawiają wręcz odmienne zamiary - okazania ironii i sarkazmu³.

\section{POLITENESS IN POLITICS}

Abstract. The aims of this article is to analyze existing categories and forms of acts of politeness in the speeches of politicians at Polish parliament. In analysis I use visual analysis method and focus on the linguistic and cultural politeness strategies and refer to the theory of the politeness (E. Goffman, P. Brown, S. Levinson).

Key words: politics, politeness, Polish politics, etiquette, deputy etiquette, savoir vivre at the parliament, apparent politeness, rules of politeness, sociology of emotions, politeness theory, face, face saving

30 ironii więcej w tekście Eweliny Sudry zawartym w tym tomie. 


\section{Bibliografia}

Brown, Penelope., Stephen Levinson (1978), Universals in Language Usage: Politeness Phenomena, [w:] Esther N. Goody (ed.), Questions and Politeness: Strategies in Social Interaction, Cambridge

Dąbrowska, Anna (1991), Sposoby kończenia rozmowy w sytuacji oficjalnej, [w:] Język a kultura, t. 6: Polska etykieta językowa, red. Janusz Anusiewicz, Małgorzata Marcjanik, Wiedza o Kulturze, Wroctaw

Doroszewski, Witold (red.) (1958-1969), Słownik Języka Polskiego, t. II, Warszawa

Dziewulak, Dobromir (2009), Precedencja Stanowisk Publicznych w Polsce, [w:] Analizy BAS, nr 2 (10)

Druk nr 43 Sejmu Rzeczpospolitej Polskiej, VII kadencja, Wniosek o wyrażenie wotum nieufności wobec Ministra Spraw Zagranicznych Radosława Sikorskiego, Warszawa, 1 grudnia 2011 r., http://orka.sejm.gov. pl/Druki7ka.nsf/0/63DA00C077F7AE63C125795F003620CB/\%24File/43.pdf [dostęp 20.06.2014]

Druk nr 2015 Sejmu Rzeczpospolitej Polskiej, VII kadencja, Wniosek o wyrażenie wotum nieufności wobec Ministra Zdrowia Bartosza Arłukowicza, Warszawa 12 grudnia 2013 r., http://orka.sejm.gov.pl/Dru-
ki7ka.nsf/0/B15CC225F4491F05C1257C4A003AB920/\%24File/2015. pdf [dostęp 20.06.2014]

Goffman, Erving (2006), Rytuat interakcyjny, przeł. Alina Szulżycka, Wydawnictwo PWN, Warszawa

Linde, Samuel Bogumił (1815), Słownik Języka Polskiego, Lwów

Marcjanik, Małgorzata (1991), Typologia polskich wyrażeń językowych o funkcji grzecznościowej, [w:] Język a kultura, t. 6: Polska etykieta językowa, red. Janusz Anusiewicz, Małgorzata Marcjanik, Wiedza o Kulturze, Wrocław

Orłowski, Tomasz (2006,) Protokół Dyplomatyczny, ceremoniat \& etykieta, Warszawa

Peisert, Maria (1991), Etykieta językowa jako przejaw edukacji społecznej i kulturowej, [w:] Język a kultura, t. 6: Polska etykieta językowa, red. Janusz Anusiewicz, Małgorzata Marcjanik, Wiedza o Kulturze, Wrocław

Tomiczek, Eugeniusz (1991), Z badań nad istotnością grzeczności językowej, [w:] Język a kultura, t. 6: Polska etykieta językowa, red. Janusz Anusiewicz, Małgorzata Marcjanik, Wiedza o Kulturze, Wrocław

Uchwała Sejmu Rzeczypospolitej Polskiej z dn. 17 lipca 1998 r. Zasady Etyki Poselskiej, „Monitor Polski” 1998, nr 24, poz. 338

\section{Netografia}

https://www.youtube.com/watch?v=U50pQyldJto https://www.youtube.com/watch?v =ATDvq8p0Ft0\&list=PLoKqIN5JjGgULPIBOswukSLCAfMijOUIY 